\title{
Pemasangan Lampu Jalan Berbasis Solar Cell untuk Penerangan Jalan di Desa Cilatak Ciomas
}

\author{
Septianissa Azzahra ${ }^{1}$; Christiono $^{2}$; Samsurizal $^{3}$; Miftahul Fikri ${ }^{4}$; Titi Ratnasari ${ }^{5}$; \\ Rizki Pratama Putra ${ }^{6}$; Dhami Johar Damiri ${ }^{7}$ \\ 1,2,3,4,5, 6,7 Departemen Elektro, Sekolah Tinggi Teknik PLN \\ ${ }^{1}$ Septianissa@sttpln.ac.id
}

\begin{abstract}
The negative impact of fossil-fueled plants and the lack of public understanding of renewable energy lies behind the holding of these PKM activities with the aim of educating and at the same time transferring technology that is directly beneficial to the community in the form of solar powered street lighting. From the surveys that have been conducted where there are no available street lighting facilities so that there are some community activities that are difficult to do at night. From this work, there were two important things, among others, that the community gained an understanding of renewable energy and knowledge to efficiently use energy to reduce the environmental impact of the dominant fossil power plant in Indonesia. The second is that with the help of solar-powered street lights, the community is very helpful in carrying out activities at night and creates more secure conditions in the community.
\end{abstract}

Keywords: Street Lamp, Renewable Energy, Solar Cell

\begin{abstract}
ABSTRAK
Dampak negatif dari pembangkit berbahan bakar fosil dan minimnya pemahaman masyarakat mengenai energi terbarukan melatarbelakangi diadakannya kegiatan PKM ini dengan tujuan mengedukasi dan sekaligus transfer teknologi yang bermanfaat langsung bagi masyarakat berupa pemasangan Penerangan Jalan Umum (PJU) bertenaga surya. Dari hasil survei yang telah dilakukan dimana sepanjang jalan masuk desa belum ada tersedianya fasilitas penerangan jalan sehingga aktivitas masyarakat menurun pada saat di malam hari. Dari hasil kegiatan ini didapatkan 2 hal penting yaitu masyarakat mendapatkan pemahaman tentang energi terbarukan beserta pemanfaatan energi secara efisien untuk mengurangi dampak lingkungan dari pembangkit listrik fosil yang dominan di Indonesia. Yang kedua adalah dengan adanya bantuan berupa lampu PJU bertenaga solar suryamasyarakat sangat terbantu untuk beraktivitas di malam hari juga menciptakan kondisi yang semakin aman di masyarakat.
\end{abstract}

Kata kunci: Penerangan Jalan Umum, Energi Terbarukan, Sel Surya 


\section{PENDAHULUAN}

Pemanfaatan energi surya sebagai alternatif bahan bakar fosil untuk membangkitkan energi listrik semakin gencar dilakukan saat ini mengingat dampak negatif dari polusi yang diakibatkan oleh pembangkit tenaga listrik berbahan fosil sudah semakin nyata. Proses migrasi dari bahan bakar fosil ke energi terbarukan seperti sinar matahari tentunya tidak dapat berlangsung instan melainkan perlu proses yang berkesinambungan melibatkan pihak masyarakat, swasta dan pemerintah ${ }^{[1]}$. Pihak masyarakat sendiri dapat diedukasi dengan memberikan sosialisasi dalam bentuk pengajaran langsung atau dengan pemberian contoh aplikasi penggunaan energi surya yang langsung dapat dimanfaatkan oleh masyarakat.

Salah satu aplikasi tenaga surya yang paling sederhana yang dapat diaplikasikan langsung ke masyarakat adalah penerangan jalan umum (PJU)bertenaga surya. Dengan sistem Penerangan Lampu Jalan Tenaga Surya dapat solusi dan memberikan sesuatu yang sangat berarti bagi masyarakat terpencil yang karena kondisi geografis dan keterbatasan pemerintah untuk membuat jaringan distribusi, hingga saat ini belum dapat menikmati listrik (PLN) ${ }^{[5]}$. Hemat, karena tidak memerlukan bahan bakar, sehingga hampir tidak memerlukan biaya operasi. Dapat di pasang dimana saja dan dapat dipindahkan bilamana dibutuhkan. Dapat diterapkan secara sentralisasi (PLTS ditetapkan di suatu area dan listrik yang dihasilkan disalurkan melalui jaringan distribusi ketempat - tempat yang membutuhkan) maupun desentralisasi (setiap system berdiri sendiri/individual, tidak memerlukan jaringan distribusi) ${ }^{[3]}$. Bersifat moduler kapasitas listrik yang dihasilkan dapat disesuaikan dengan kebutuhan dengan cara merangkai modul secara seri dan pararel. Dapat dioperasikan secara otomatis (unattendable) maupun dengan operasi (attendable). Tanpa suara dan tidak menimbulkan polusi lingkungan.

Penerapan PJU bertenaga surya sekaligus sosialisasi pemanfaatan energi surya dalam program PKM ini akan dilakukan di Desa Cilatak di kecamatan Ciomas Provinsi Banten. Ada beberapa pertimbangan yang diambil sehingga kampung ini dipilih sebagai tempat sosialisasi. Kampung Cilatak termasuk salah satu dari sekian kampung di kecamatan ciomas yang memiliki penerangan jalan yang minim, sehingga warga sekitar mengalami kesulitan melakukan aktifitas khususnya dimalam hari. Oleh karenanya penerangan jalan umum dikampung menjadi suatu hal yang sangat dibutuhkan warga sekitar, untuk melakukan aktiftas dimalam hari seperti ke masjid, mengaji dll.

Berdasarkan hal yang telah disebutkan diatas maka penulis akan melakukan kegiatan Program Kemitraan Masyarakat dilokasi tersebut dengan judul "Pemasangan Lampu Jalan Berbasis Solar Cell Untuk Penerangan Jalan Di Desa Cilatak Ciomas". Dan adapun tujuan yang hendak dicapai dalam kegiatan tersebut diantaranya adalah:

- Mengedukasi masyarakat tentang sumber energi terbarukan dan teknologi serderhana yang berkaitan dan bermanfaat langsung ke masyarakat seperti PJU bertenaga surya.

- Memperbaiki/meningkatkan mutu sumber daya manusia melalui perbaikan sarana penunjang pembelajaran dan aktivitas warga yaitu fasilitas umum berupa lampu penerangan jalan.

- Membangun relasi langsung antara perguruan tinggi dan masyarakat dengan penyelesaian masalah dimasyarakat oleh akademisi sehingga kegiatan Tri Darma Perguruan Tinggi dapat terwujud. 


\section{METODE}

Kegiatan ini dilakukan tepatnya di desa Cilatak, Kecamatan Ciomas, Kabupaten Serang, Provinsi Banten. Adapun waktu pelaksananaannya dari kegiatan survey hingga pemasangan modul adalah 1 minggu.

Seluruh rangkaian kegiatan dapat dilihat dalam bagan alir dibawah ini

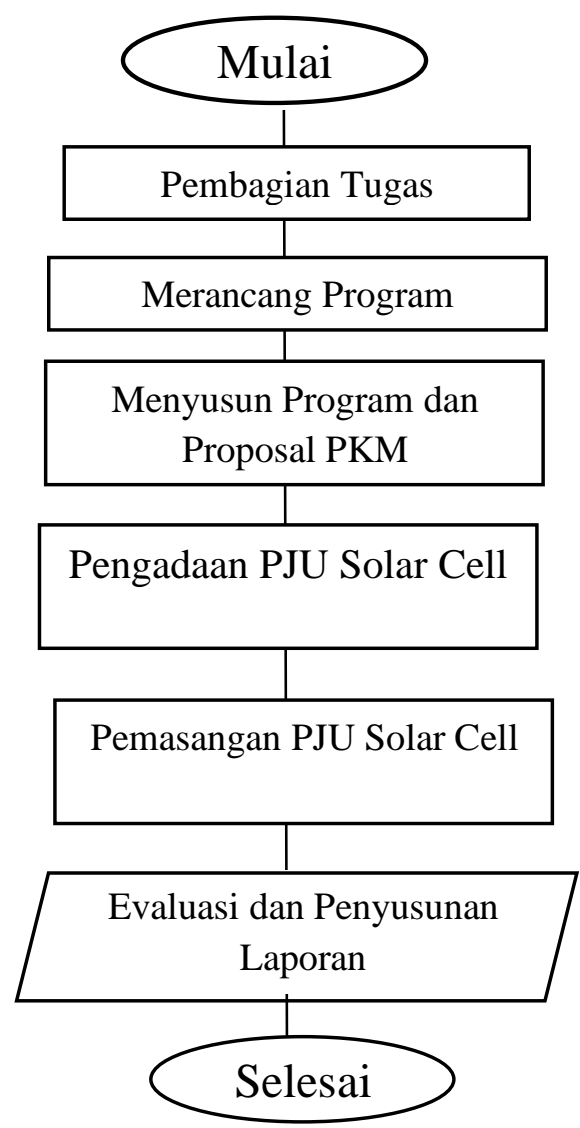

Gambar 1. Diagram Alir PKM

Berdasarkan masalah mitra masyarakat yang telah disebutkan sebelumnya yaitu kurangnya pengetahuan mengenai energi terbarukan dan juga fasilitas penerangan jalan umum yang tidak memadai maka beberapa metode diusulkan dalam kegiatan ini diantaranya yaitu dengan mengadakan pendidikan, konsultasi, difusi ipteks langsung ke masyarakat.

Pendidikan dan konsultasi mengenai energi terbarukan dan teknologi penerangan jalan umum diberikan dalam sutu kegiatan pemaparan materi interaktif terhadap warga kampung. Materi diberikan dengan bahasa yang mudah dimengerti/dipahami, dalam pemaparan materi ditekankan mengenai kelebihan dan kekurangan dari penggunaan PJU bertenaga surya dengan PJU biasa.

Setelah itu modul PJU bertenaga surya diperagakan di depan warga untuk menjelaskan prinsip kerja dan bagaimana perawatan dan pemasangan modul tersebut. Sehingga diharapkan dapat terjadi difusi ipteks secara langsung ke masyarakat. 


\section{HASIL DAN PEMBAHASAN}

Kegiatan ini di lakukan selama 3 hari yaitu pada tanggal 4 - 6 April 2019 di Kampung Cilatak RT.11 RW.03 Desa Sukadana Kecamatan Ciomas Kabupaten Serang, Banten. Pelaksanaan Program Kemitraan Masyarakat berupa pemasangan lampu jalan berbasis solar sel untuk penerangan jalan ini diikuti oleh 25 orang warga dimana sebagai awal acara dibuka dengan sambutan dari Kepala Desa Sukadana. Kegiatan PKM secara garis besar terbagi menjadi 2 yang pertama yaitu kegiatan sosialisasi atau penyampaian materi dan yang kedua adalah proses pemasangan PJU.

\subsection{Sosialisasi Mengenai Energi Terbarukan Dan Pengenalan Teknologi PJU Bertenaga Surya}

Dari kegiatan PKM mengenai pemasangan lampu jalan berbasis solar sel untuk penerangan jalan di Desa Cilatak, Ciomas yang telah dilakukan, masyarakat terlihat telah memahami konsep dasar dalam penerangan jalan serta penerapan dan pemanfaatannya dalam kehidupan sehari-hari melalui berbagai pamaparan materi yang disampaikan.

Dalam pemaparan materi yang dilakukan terbagi menjadi beberapa sesi, yang pertama yaitu pemaparan tentang pentingnya sumber energi terbarukan dan dampak negatif dari penggunaan energi fosil yang selama ini sebagian besar dilakukan oleh PLN untuk menghasilkan energi listrik.

Sesi kedua diberikan materi tentang teknologi penerangan jalan umum bertenaga surya. Dalam sesi ini ditekankan kelebihan penggunaan PJU bertenaga surya dibandingkan lampu PJU konvensional diantaranya yaitu:

- Terang dan tahan lama

- Hemat energi tanpabiayalistrik

- Ramah lingkungantanpapolusi

- Cepat dan mudahdalampemasangan

- Perawatan mudah

Dalam sesi ini juga diperagakan PJU yang akan dipasang dan dijelaskan setiap bagiannya pada warga dengan bahasa yang mudah dimengerti.

Materi selanjutnya berisi penjelasan pada warga mengenai perawatan PJU bertenaga surya. Warga diberitahu agar melakukan pembersihan rutin minimal 2 kali setahun yaitu pada musim kemarau yang dikhawatirkan terjadi penumpukan debu pada panel surya PJU.

\subsection{Pemasangan PJU Bertenaga Surya}

Pemasangan PJU bertenaga surya dilakukan oleh tim dan dibantu oleh warga sekitar. Sebelum proses pemasangan dilakukan terlebih dahulu dilakukan briefing atau pengarahan kepada warga yang akan membantu mengenai titik atau lokasi pemasangan lampu berikut prosedur pemasangan dan keselamatan.

Setelah melakukan persiapan daan berkoordinasi dengan warga Desa Sukadana, kegiatan dilanjutkan dengan pemasangan lampu jalan berbasis solar sel untuk penerangan jalan di desa Sukadana. Jumlah total lampu yang dipasang adalah 6 unit. Dan PJU tersebut dipasang pada tiang beton miliki PLN yang saat ini digunakan untuk menyangga kabel tegangan rendah ke rumah warga. 


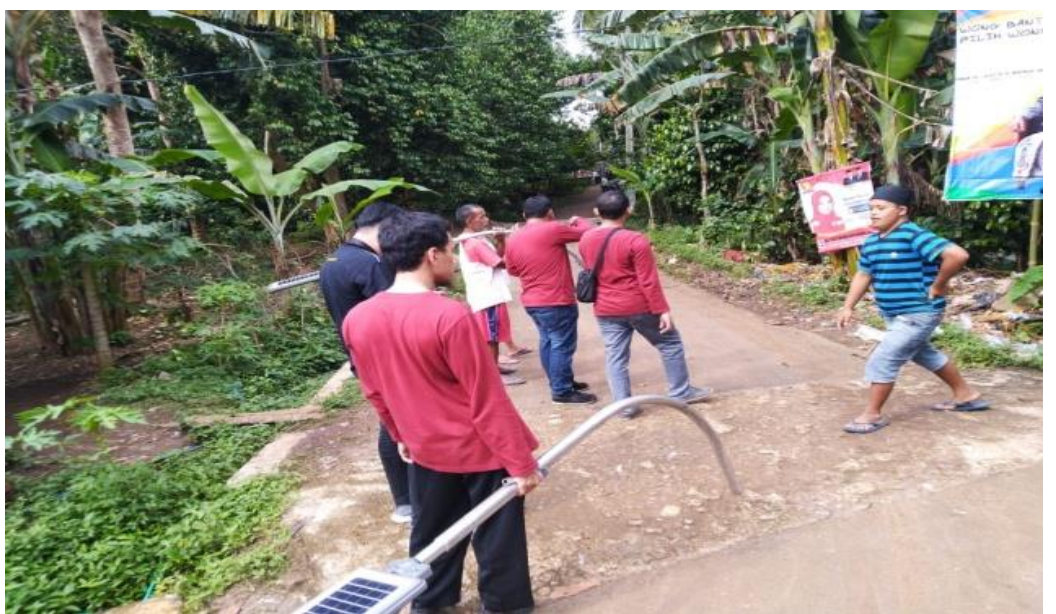

Gambar 2. Pemasangan Lampu Jalan Berbasis Solar Cell
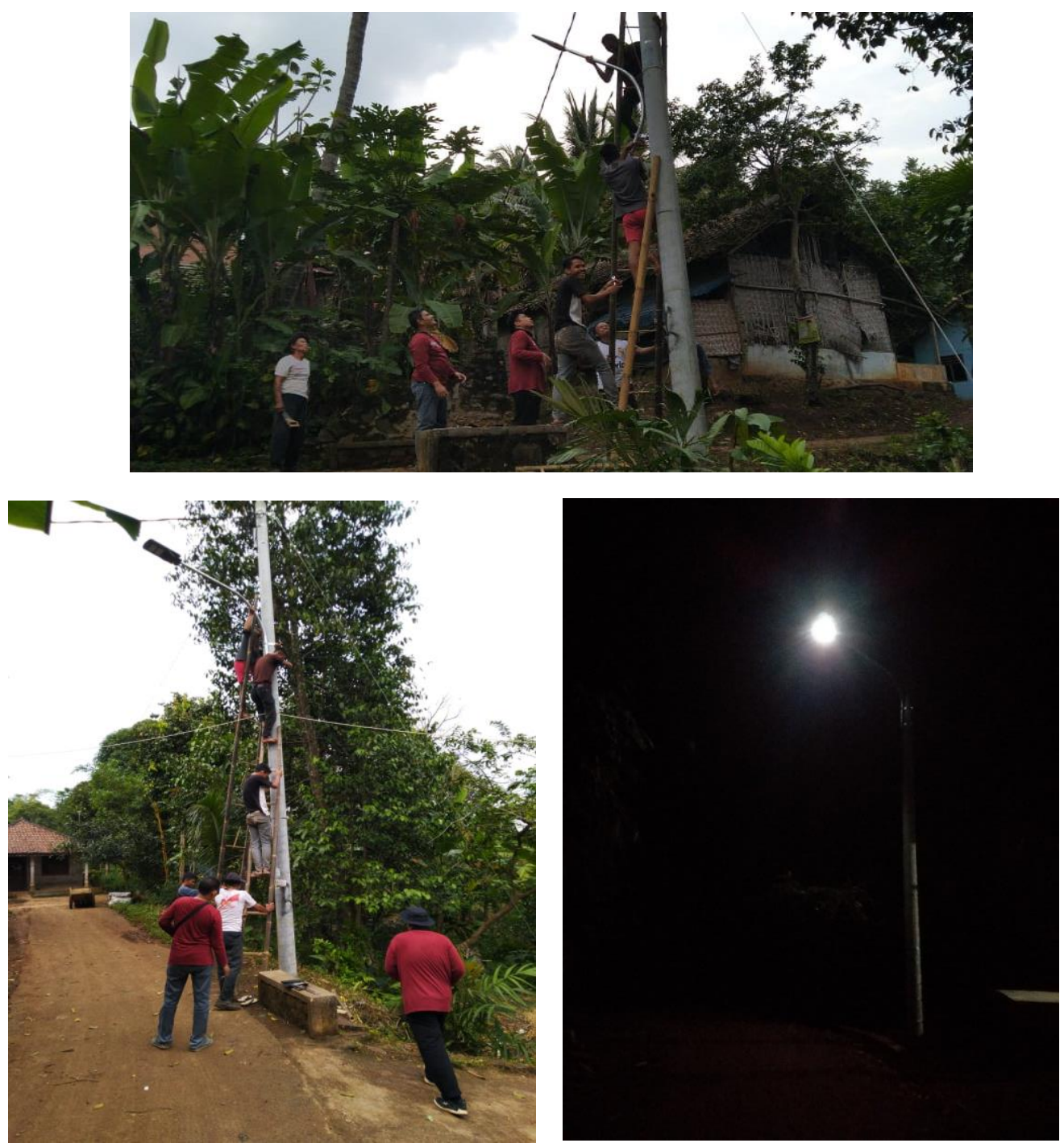

Gambar 3. Pemasangan Lampu Jalan Berbasis Solar Cell 
Setelah pemasangan dilakukan, kemudian pada malam hari PJU yang terpasang ditinjau kembali untuk mengecek apakah telah beroperasi sesuai yang diharapkan, dan juga apakah kehadiran PJU di lokasi tersebut sudah memberikan manfaat langsung ke masyarakat.

\subsection{Kendala Yang Dihadapi}

Dalam pelaksanaan Program Kemitraan Masyarakat (PKM) yang dilakukan pada tanggal 4-6 April 2019, pada dasarnya tidak mengalami kendala yang berarti. Hanya saja waktu pelaksanaan kegiatan sedikit terlambat dikarenakan pada hari pertama kedatangan tim terkendala dengan kemacetan pada jalan yang dilalui.

\subsection{Evaluasi}

Pelaksanaan kegiatan PKM sudah berjalan dengan baik. Untuk kegiatan PKM yang selanjutnya diharapkan tim dapat menjaga kekompakan dan kinerja yang sudah sangat baik sehingga dikegiatankegiatan selanjutnya dapat berjalan lebih baik lagi.

\section{KESIMPULAN}

Adapun kesimpulan yang dapat diambil dari kegiatan ini adalah:

- Kegiatan PKM atau program kemitraan masyarakat tentang sosialisasi energi terbarukan dan pemanfaatannya yang dirangkaikan dengan pemasangan PJU bertenaga surya memberikan hasil yang baik dimasyarakat yaitu meningkatkan pemahaman warga mengenai energi terbarukan dan juga memberikan manfaat nyata bagi warga dengan pemasangan PJU bertenaga surya

- Kegiatan ini juga memberikan suatu realisasi hubungan langsung yang saling menguntungkan antara akademisi dan warga masyarakat

- Program PKM yang dilakukan selain membentuk hubungan langsung antara kampus dan masyarakat juga sebagai sumbangsih pada pemerintah setempat dalam membangun dan membina desa.

\section{SARAN}

Berdasarkan kegiatan yang telah dilakukan, diharapakan Tim PKM dapat melakukan kegiatan pemasangan lampu jalan berbasis solar sel untuk penerangan jalan di desa-desa lainnya yang masih belum memiliki penerangan jalan agar tiap-tiap desa yang kami kunjungi dapat merasakan manfaatnya dan dapat digunakan serta dijaga sebagai mana mestinya.

\section{UCAPAN TERIMA KASIH}

Penulis mengucapkan terima kasih kepada STTPLN melalui LPPM-STTPLN atas bantuan dana yang diberikan. Kemudian juga kepada pihak lurah dan warga desa cilatak yang telah membantu sehingga kegiatan ini berjalan dengan sukses.

\section{DAFTAR PUSTAKA}

[1] Abdul Kadir. 2010. Energi Sumber Daya, Inovasi, Tenaga Listrik dan Potensi Ekonomi, Penerbit U.I Edisi ke 3/Revisi.

[2] B. K. Bose. 2010. Global warming: Energy, environmental pollution, and the impact of power electronics. IEEE Industrial Electronics Magazine 4.1, pp. 6-17. 
[3] Duffie, A William, William A. Beckman. 2008. Solar Engineering Of Thermal Processes. John Wiley \& Sons. Newyork.

[4] Fraas, Lewsi, Larry Partain. Solar Cells and Their Applications, Second Edition. John Wiley \& Sons. Newyork.

[5] Sutarno, 2013. Sumber Daya Energi. Graha Ilmu. Yogyakarta.

[6] T.T. Gultom. 2017. Pemenuhan Sumber Tenaga Listrik di Indonesia. Jurnal Ilmiah Research Sains, Vol. 3.1.

[7] W. B. B. A. M. R. R. \& S. T. Anhar. 2018. Perhitungan Lampu Penerangan Jalan Berbasis Solar System. Jurnal Sains Terapan. Vol.4(1), pp. 33-36. 